\title{
Influence of Duration of Agroforestry on Physico-Chemical Soil Quality Parameters in
}

\section{Machakos County, Kenya}

$\underline{\text { Benjamin Mutuku Kinyili }^{\mathrm{a}}}$, Ezekiel Ndunda ${ }^{\mathrm{b}}$, Esther Kitur ${ }^{\mathrm{b}}$

\author{
${ }^{a}$ Kenya Forest Services, PO Box 2501-30100, Eldoret, Kenya, Email: bmkinyili@ yahoo.com \\ ${ }^{\mathrm{b}}$ Department of Environmental Science, Kenyatta University, PO Box 43844-00100, Nairobi,
} Kenya

Keywords: Agroforestry, physico-chemical parameters, Soil quality, Duration of agroforestry, soil chemical parameters

\begin{abstract}
The role of agroforestry in improving soil quality is well appreciated. However, there is debate as to how duration of agroforestry practice affects soil quality especially in the tropical region of Sub Saharan Africa where adoption of the practice is fairly recently. Therefore, objective this study was to investigate the influence of duration of agroforestry on physicochemical soil quality parameters. The study was conducted using survey research design from a sample of 73 individual farmers, selected using stratified and random sampling. Soils were sampled from adopters and non adopters using soil auger. At least five sub-samples of soils were collected from each of the farmers and the soil mixed to get an integrated soil sample for analysis. The soil were packaged in two-kg khaki papers and taken to the laboratory for further physical attributes (sand, clay, silt and bulk density) and chemical analyses ( $\mathrm{pH}, \mathrm{TN}$, $\mathrm{TP}, \mathrm{TOC}, \mathrm{C} / \mathrm{N}$ and $\mathrm{C} / \mathrm{P}$ ). The exchangeable bases $(\mathrm{K}, \mathrm{Ca}, \mathrm{Mg}$ and $\mathrm{Na}$ ) as well as micronutrients $(\mathrm{Mn}, \mathrm{Cu}, \mathrm{Fe}$ and $\mathrm{Zn})$ were also analyzed. The results indicated that proportion of sand particles was significantly $(P<0.05)$ higher among non adopters compared to adopters while silt and bulk density was significantly $(P<0.05)$ higher among the adopters compared to the non adopters. Sand particle decreased with increasing duration of agroforestry adoption while proportion of silt and bulk density showed a significant increase in tandem to stand duration of agroforestry. The TN, TOC and C/P ratio was significantly ( $P$ $<0.05)$ higher among adopters and increased consistently with age of adoption, while $\mathrm{C} / \mathrm{N}$ was higher among non adopters and decreased with increasing age of tree stand and duration of agroforestry. The trend in exchangeable bases and mineral contents in the soil were similar where higher concentrations occurred among adopters and displayed an increase with regard to length of adoption of agroforestry. The current study lends support to assertion that duration of agroforestry positively improves soil quality and therefore urges for mass adoption of the agroforestry practice to enhance increased agricultural productivity.
\end{abstract}

DOI: 10.33803/JASETD.2020.4-1.4 


\section{Introduction}

Agroforestry practices encompass an entire spectrum of land use systems in which woody perennials are deliberately combined with agricultural crops and/or animals in some spatial or temporal arrangement (Abbas et al., 2017). The high productivity and sustainable land use makes adoption of agroforestry ubiquitous at the global scale (Dalemans et al., 2018; McAdam \& Curran, 2018; Fleming et al., 2019). Agroforestry practices have demonstrated reducing or reversal of land degradation, sequestration of carbon from the atmosphere and securing rural livelihoods through provision of economic benefits mostly in rural areas (Catacutan et al., 2017; Montagnini \& Metzel, 2017; Waldron et al., 2017; Saqib et al., 2019). Agroforestry also provide ecosystem services and functions in addition to the products and services that motivate farmers to plant them (Kuyah et al., 2017). These services are of particular importance in many low-income countries especially in Sub Saharan Africa, where large proportions of the populations work in an agricultural sector that does not attract much investment from either government or private sector (Meijer et al., 2015; Benjamin \& Sauer, 2018). As a result most of the new adopters of agroforestry reside in the tropical region of the world where conditions are favourable (Tscharntke et al., 2011; Atangana et al., 2013; 2014). Most of the adoption practices of agroforestry among smallholder farmers in Sub Saharan African occurred over the last five decades (Franzel et al., 2001; Leakey et al., 2005; Meijer et al., 2015; Beyene et al., 2019). Nevertheless, the exact duration of agroforestry adoption in the region remains largely unknown and therefore factors associated with adoption may vary widely.

While agroforestry can provide a number of environmental benefits, and play key roles in ecosystem services, there is also increasing focus of its effects on soil quality (Cardinael $e t$ al., 2015; Weerasekara et al., 2016; Udawatta et al., 2017; Dollinger \& Jose, 2018). 
Proponents of agroforestry contend that soil conservation is one of its primary benefits (García de Jalón et al., 2017; Sarminah et al., 2018). In this case, the cover function involves reducing raindrop impact and wind action on soil particles by increasing soil cover through litter and pruning. The most widely held view is that trees in agroforestry systems can improve soil quality mainly by biological nitrogen $(\mathrm{N})$ fixation and increasing the amounts of aboveground and belowground organic matter inputs (Isaac \& Borden, 2019; Sarabia et al., 2020). There are a number of benefits that are directly related to soil quality including preventing soil erosion through surface litter cover and under story vegetation (Akdemir et al., 2016; Béliveau et al., 2017), improving water infiltration (Sahin et al., 2016), increasing soil moiture (Cardinael et al., 2017; Feliciano et al., 2018), maintaining soil fertility (Liu et al., 2018), enhancing water dynamics (Ling et al., 2017; Hasselquist et al., 2018), conserving soil biodiversity (Torralba et al., 2016), improving soil microbial biomass (Buyer et al., 2017) and mitigation of climate change by carbon sequestration (Newaj et al., 2016; Hasselquist et al., 2018). To understand the dynamics of the impacts of agroforestry on soil requires an understanding of the soil quality parameters.

Soil's capacity to sustain biological productivity can be estimated by the evaluation of physical, chemical and biological parameters (Bünemann et al., 2018). Trees in agroforestry improve soil quality by fixing atmospheric $\mathrm{N}_{2}$ which ultimately increase soil Nitrogen content (Nasielski et al., 2015; Bayala et al., 2018). Through root system accumulation and litter fall, agroforestry trees concentrates nutrients near the soil surface (Solanki \& Arora, 2015; Bhatt et al., 2017). Trees may also enhance above and below ground microclimate (Desta et al., 2018; Kar et al., 2019), while mesofauna and microfauna and microflora around plant roots may alter soil chemical, biological, and physical properties (Bhaduri et al., 2017; Lenci et al., 2018). 
In Sub Saharan African, there is a large body of literature which describe the effects of agroforestry on soils and all have highlighted that agroforestry practices could effectively improve soil physical, chemical and biological properties and maintain long-term land productivity (Githae et al., 2011; Lagerlöf et al., 2014; Bayala et al., 2018; Corbeels et al., 2019). Although the beneficial effects of agroforestry on soil quality is overwhelming, it is still not clear the impact of stand age and duration of agroforestry on soil nutrient dynamics under the influence of agroforestry systems. Therefore, the objective of this study was to determine how duration of agroforestry adoption affects soil nutrient dynamics in the Sub Saharan soils, Machakos County in Kenya.

\section{Methods}

\subsection{Study Area}

The study was conducted in Machakos County (Figure 1) which covers an area of 5,953 $\mathrm{km}^{2}$. It lies between latitudes $0^{\circ} 45^{\prime}$ South and $1^{\circ} 31^{\prime}$ South and longitudes $36^{\circ} 45^{\prime}$ East and $37^{\circ} 45^{\prime}$ East. Most of the land is semi-arid with population of $1,098,584$ as per the 2009 Kenya National census (Kenya National Bureau of Statistics, 2010). Administratively the county is divided into 11 divisions: Kalama, Kangundo, Kathiani, Machakos Central, Masinga, Matungulu, Mavoko, Mwala, Ndithini, Yathui and Yatta. In terms of political structure, the county has eight constituencies including: Kangundo, Kathiani, Machakos Town, Masinga, Matungulu, Mavoko, Mwala and Yatta. There are overlaps between divisions and constituencies were they are in most cases referred to as sub counties. Among the division and constituencies, Kathiani, Mavoko and Machakos Town practice agroforestry. Four sites where agroforestry are practiced included: Mua (Mavoko, Machakos Town and Kathiani) and 
Iveti Hills (Machakos Central and Kathiani), Kima-Kimwe and Kalama in Machakos Constituency.

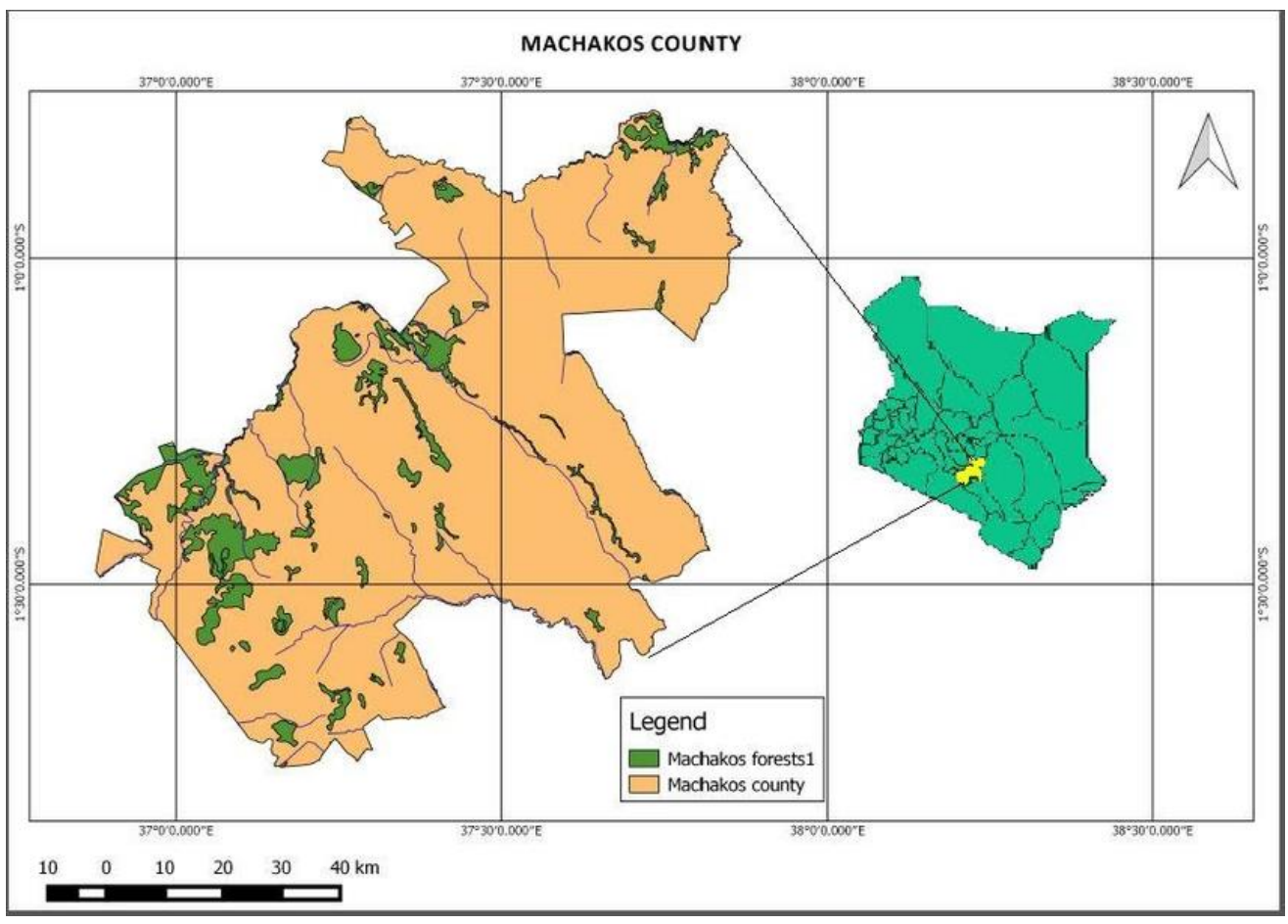

Figure 1: Map of Machakos County showing the study area

The local climate is semi-arid with hilly terrain and an altitude of 1000 to 2100 metres above sea level. The area is composed of hilltops rising to $1594-2100 \mathrm{~m}$ above sea level. The annual average rainfall is $1000 \mathrm{~mm}$ (range, $500 \mathrm{~mm}$ to $1300 \mathrm{~mm}$ ), and is bimodal; short rains occur in October to December and long rains in March to May. Temperatures range between $18.7^{\circ} \mathrm{C}$ and $29.7^{\circ} \mathrm{C}$. The soils are well drained shallow dark red volcanic on hilltops and clay soils in the plains. Irrigation farming is practiced utilizing the permanent rivers and streams that flow from the hilltop catchment areas towards South Eastern to join Athi River. Crop such as maize, beans, pigeon peas, vegetables are dominant. Dairy and beef cattle, sheep, and goats are the major livestock kept. 


\subsection{Soil sampling, data and statistical analysis}

Soils were sampled from adopters and non adopters using soil auger. At least five subsamples of soil were collected from each of the farmers and the soil mixed to get an integrated soil sample for analysis. The soil were packaged in two-kg khaki papers and taken to the laboratory for further analyses.

Bulk density measurements were made in triplicate in each study plot using coring devices (42.2 $\mathrm{mm}$ diameter polyvinyl chloride PVC tubes) carefully driven into the soil to avoid compaction. Bulk density was calculated from oven-dried soil core weight and volume. Soil structure was determined by visual inspection.

Soil samples were collected from seventy three farmers for both adopter and non-adopter farms for physico-chemical characteristics and soil fertility test for $\mathrm{N}, \mathrm{P}, \mathrm{K}, \mathrm{Ca}, \mathrm{Mg}$ and micro-nutrients which was done at Kenyatta University Laboratory and Kenya Agricultural and Livestock Research Organization (KALRO) laboratory at Machakos and Nairobi Kabete laboratories. Secondary sources, on the other hand, involved retrieving information from desk research where journals, books and other relevant literature were obtained.

Difference in soil parameters between the adopters and non adopters was determined $t$-test. All analyses were declared significant at $P<0.05$. 


\section{Results and Discussion}

\subsection{Physical attributes of the soils}

The physical attributes of the soil sampled between farmers practicing agroforestry and those not practising were determined as shown in Table 1.

Table 1: Physical attributes of the soil between farmers practicing and those not practising agroforestry

\begin{tabular}{lllll}
\hline Age of adoption & Sand & Clay & Silt & Bulk density \\
\hline 0 (Non adopter) & $62.15 \pm 0.69$ & $28.52 \pm 0.23$ & $9.13 \pm 0.58$ & $10.36 \pm 0.22$ \\
$1-5$ & $60.75 \pm 0.99$ & $28.59 \pm 0.26$ & $10.42 \pm 1.14$ & $10.47 \pm 0.17$ \\
$6-10$ & $60.41 \pm 1.37$ & $28.47 \pm 0.24$ & $11.08 \pm 1.53$ & $10.39 \pm 0.11$ \\
$11-20$ & $58.99 \pm 1.11$ & $28.49 \pm 0.20$ & $11.45 \pm 2.13$ & $10.58 \pm 0.13$ \\
$>20$ & $57.15 \pm 0.67$ & $28.53 \pm 0.19$ & $13.71 \pm 2.28$ & $10.76 \pm 0.18$ \\
ANOVA & & & & \\
F & 50.598 & 0.494 & 13.577 & 13.634 \\
df & 4 & 4 & 4 & 4 \\
P & 0.0000 & 0.7403 & 0.0000 & 0.0000 \\
\hline
\end{tabular}

Sandy particles proportion in the soil ranged from $56 \%$ to $63.2 \%$ among adopters and $61.2 \%$ to $63.2 \%$ for the non adopters of agroforestry. Based on the age and duration of agroforestry adoption, the proportion of sand on agroforestry adopters for 1-5 years was $60.75 \pm 0.99 \%$, $60.41 \pm 1.37 \%$, for those with 6-10 years adoption, $58.99 \pm 1.11 \%$ among farmers with $11-20$ years of agroforestry practice and $58.99 \pm 1.11 \%$ for farmers with 20 years practice of agroforestry. Further statistical analysis indicated that there were significant differences in percentage of sand based on the duration of agroforestry practice $(P<0.05)$. Generally the proportion of sand particles was higher among non adopters compared to adopters of agroforestry and decreased in proportion with duration of agroforestry adoption and practise (Figure 2). The present studies indicate that agrofororestry resulted in reduced proportion of sand in the soil which concurs with other studies (Pandey et al., 2000; Puttaso et al., 2011; Bhatt et al., 2017; Cardinael et al., 2017; Hewins et al., 2017). The decrease in sand particles 
could probably be due to the fact that the agroforestry tree species adopted contributed to the process of leaf litter and soil microbes helped in decomposition and may therefore result in reduction of sandy particles (Weerasekara et al., 2016). Agroforestry also increase soil organic matter which increases the proportion of silt and other organic debris in the soil at the expense of sand particles (Weerasekara et al., 2016).
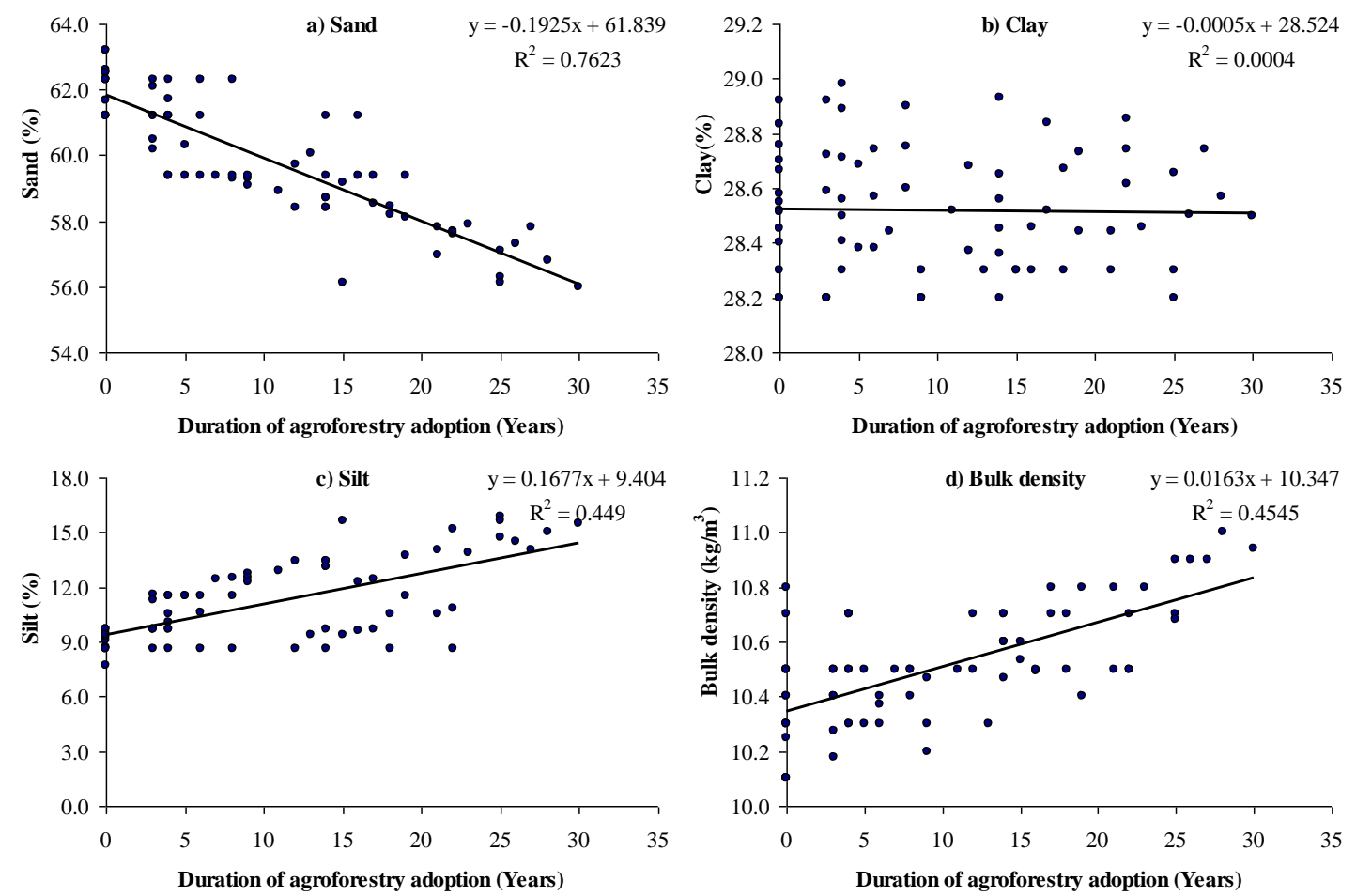

Figure 2: Physical attributes of the soil sampled among farmers with different durations of agroforestry adoption

The percentage of clay in the soil ranged from $28.2-28.98 \%$ in soils practicing agroforestry while those that were not, the proportion of clay particle were $28.2-28.9 \%$. Generally the percentage of clay where agroforestry is practiced for 1-5, 6-10, 11-20 and over 20 years did not change substantially between 28.59 to $28.9 \%$. Subjected to further analysis, the results indicated that there was no differences in the clay particles between agroforestry adopters and non adopters $(P>0.05)$ regardless duration of agroforestry practice which concurs with other studies (Alfaia, 2004; Alam et al., 2010; Akdemir et al., 2016) probably due to the overall 
nature of the soil being in semi arid landscape and may also be related to the inability of the tree litter to add much clay to the existing soils. Clay soil are result of microbial degradation of the soil and organic matter particles (Cardinael et al., 2017) which was not possible under the condition of the soils in Machakos County.

The percentage of silt in the soil ranged from 8.6-15.9\% in soils with agroforestry practices but in soil without any agroforestry practice, the proportion of silt was 7.7-9.7\%. The percentage of silt among framers with $1-5$ years agroforestry practice was $9.13 \pm 0.58 \%$, those with 6-10 years practice it was $11.08 \pm 1.53 \%$, then for farmers with $11-20$ years of agroforestry practice it was $11.45 \pm 2.13 \%$ while those with 20 years of agroforestry practice the percent was $13.71 \pm 2.28 \%$. Further statistical analysis indicated that there was a significant difference in percentage of silt based on the duration of agroforestry practice $(P<$ 0.05). These results indicate that the proportion of silt was significantly higher among the adopters compared to the non adopters and increased with increasing age and duration of agroforestry adoption. Increased proportion of silt in soil where agroforestry is practiced has been widely reported (Li et al., 2015; Bhaduri et al., 2017; Deng et al., 2017; Dhaliwal et al., 2019). Silt particles are formed due to decomposition of soil organic matter, allochthonous organic matter as well as soil microbial and biochemical processes (Hassink, 1997; Paul, 2016) which appears to originate from the agroforestry trees and thus agroforestry appears to improve the silt content of the soil, which was confirmed by the increasing silt with age and duration of agroforestry adoption.

The bulk density in the soil ranged from $10.18-11.00 \mathrm{~kg} / \mathrm{m}^{3}$ in soils where agroforestry was practiced but in soil without any agroforestry practice, the bulk density was $10.1 .-10.8 \mathrm{~kg} / \mathrm{m}^{3}$. The bulk density in soils for farmers with $1-5$ years agroforestry practice was $10.47 \pm 0.17$ 
$\mathrm{kg} / \mathrm{m}^{3}$, those with $6-10$ years practice it was $10.39 \pm 0.11 \mathrm{~kg} / \mathrm{m}^{3}$, then among farmers with 11 20 years of agroforestry practice it was $10.58 \pm 0.13 \mathrm{~kg} / \mathrm{m}^{3}$ and those with 20 years of agroforestry practice the percent was $10.76 \pm 0.18 \mathrm{~kg} / \mathrm{m}^{3}$. Further statistical analysis indicates that there was a significant difference in bulk density based on the duration of agroforestry practice $(P<0.05)$. Bulk density in the soil was higher among the adopters as compared to the non adopters and increased with increasing duration of agroforestry adoption. These studies concurs with those of those of (Udawatta \& Anderson, 2008; Udawatta et al., 2009; Gama-Rodrigues et al., 2010; Silva et al., 2011; Chaudhari et al., 2013) who showed a significant increase in soil bulk density associated with agroforestry practices. The increase in bulk density in the soil could be due to increased compaction of the soil (Hairiah et al., 2006), addition of organic matters from decomposition leaves (Udawatta et al., 2006) and wood debris in the soil. However, the current results differed from those by (Throop et al., 2012) who showed no differences in the bulk density between agroforestry adopters and non adopters. The authors did not provide any explanation and thus it is not clear why the current results differ from those of these authors.

\subsection{Chemical composition of the soils}

The $\mathrm{pH}$, and concentration of TN, TP, TOC, $\mathrm{C} / \mathrm{N}$ and $\mathrm{C} / \mathrm{P}$ ratios in the soils between farmers with different duration of agroforestry adoption in Machakos County are provided in Table 2. 
Table 2: Chemical composition in the soils between farmers with different duration of agroforestry adoption in Machakos County

\begin{tabular}{|c|c|c|c|c|c|c|}
\hline $\begin{array}{l}\text { Age of } \\
\text { adoption }\end{array}$ & $\mathrm{pH}$ & TN & $\mathrm{TP}$ & TOC & $\mathrm{C} / \mathrm{N}$ & $\mathrm{C} / \mathrm{P}$ \\
\hline 0 & $\begin{array}{l}6.33 \pm \\
0.34\end{array}$ & $0.04 \pm 0.01$ & $\begin{array}{l}83.83 \pm \\
21.95\end{array}$ & $1.09 \pm 0.25$ & $12.06 \pm 3.57$ & $0.01 \pm 0.01$ \\
\hline $1-5$ & $\begin{array}{l}6.26 \pm \\
0.29\end{array}$ & $0.14 \pm 0.04$ & $\begin{array}{l}77.61 \pm \\
24.21\end{array}$ & $1.50 \pm 0.25$ & $9.95 \pm 2.40$ & $0.02 \pm 0.01$ \\
\hline $6-10$ & $\begin{array}{l}6.02 \pm \\
0.31\end{array}$ & $0.14 \pm 0.05$ & $\begin{array}{l}67.47 \pm \\
29.04\end{array}$ & $1.61 \pm 0.30$ & $9.23 \pm 1.60$ & $0.02 \pm 0.01$ \\
\hline $11-20$ & $\begin{array}{l}6.06 \pm \\
0.27\end{array}$ & $0.19 \pm 0.03$ & $\begin{array}{l}74.91 \pm \\
19.21\end{array}$ & $1.97 \pm 0.25$ & $9.31 \pm 1.74$ & $0.03 \pm 0.01$ \\
\hline$>20$ & $\begin{array}{l}6.28 \pm \\
0.39\end{array}$ & $0.26 \pm 0.05$ & $\begin{array}{l}82.00 \pm \\
21.82\end{array}$ & $2.26 \pm 0.32$ & $8.08 \pm 1.73$ & $0.03 \pm 0.01$ \\
\hline ANOVA & & & & & & \\
\hline $\mathrm{F}$ & 2.2145 & 30.673 & 1.6423 & 3.951 & 5.4453 & 7.1121 \\
\hline df & 4 & 4 & 4 & 4 & 4 & 4 \\
\hline $\mathrm{P}$ & 0.1342 & 0.0003 & 0.2373 & 0.0000 & 0.0237 & 0.0071 \\
\hline
\end{tabular}

The $\mathrm{pH}$ of the soil ranged from 5.42-6.80 in agroforestry soils but was 5.53-6.82 in soil without agroforestry practice. The $\mathrm{pH}$ in soils where agroforestry was being practiced for 1-5 years was $6.26 \pm 0.29$, those with $6-10$ years practice it was $6.02 \pm 0.31$, for $11-20$ years of agroforestry practice it was $6.06 \pm 0.27$ and those with 20 years of agroforestry practice the percent was $6.28 \pm 0.39$. Statistical analysis indicates that there was no a significant difference in $\mathrm{pH}$ based on the duration of agroforestry practice $(P>0.05)$. This indicates similarity in the soil $\mathrm{pH}$ between the adopters and non adopters, which concurs with several studies (Behera et al., 2015; Singh, 2016; Rocha Junior et al., 2018; Sousa Neto et al., 2018; $\mathrm{Yu}, 2018$ ). The lack of differences in $\mathrm{pH}$ may be attributed to the soil geology being over similar $\mathrm{pH}$ ranges and most trees planted rarely affect soil $\mathrm{pH}$. The planting of trees did not use lime or fertilizers that may affect the soil $\mathrm{pH}$ and therefore may be the reason for the 
observed similarity in the soil $\mathrm{pH}$ between agroforestry adopters and agroforestry non adopters.

The TN of the soil ranged from $0.07-0.30 \mathrm{ppm}$ in agroforestry soils but was $0.02-0.07$ in soil without any agroforestry practice. The TN in soils for farmers with 1-5 years agroforestry practice was $0.14 \pm 0.04 \mathrm{ppm}$, those with $6-10$ years practice it was $0.14 \pm 0.05 \mathrm{ppm}$, among farmers with 11-20 years of agroforestry practice it was $0.19 \pm 0.03 \mathrm{ppm}$ and those with 20 years of agroforestry practice the percent was $0.26 \pm 0.05 \mathrm{ppm}$. Further statistical analysis indicated that there was a significant difference in TN based on the duration of agroforestry practice $(P<0.05)$. The results show that the proportion of TN was significantly higher among the adopters compared to the non adopters and increased with increasing age and duration of agroforestry adoption (Figure 3). Increased proportion of $\mathrm{TN}$ in soil has been reported to occur in soils with long history of agroforestry (Lu et al., 2015; Gurmessa et al., 2016; Kim et al., 2016; Weerasekara et al., 2016; Atapattu et al., 2017). Total Nitrogen in soil increased due to decomposition of leaves, use of nitrogenous fertilizers during planting of vegetables and autochthonous organic matter within the agroforestry practice complex. These results indicate that long term practice of agroforestry therefore increased nitrogen in the soil through nitrification and microbial breakdown of the leaves. 

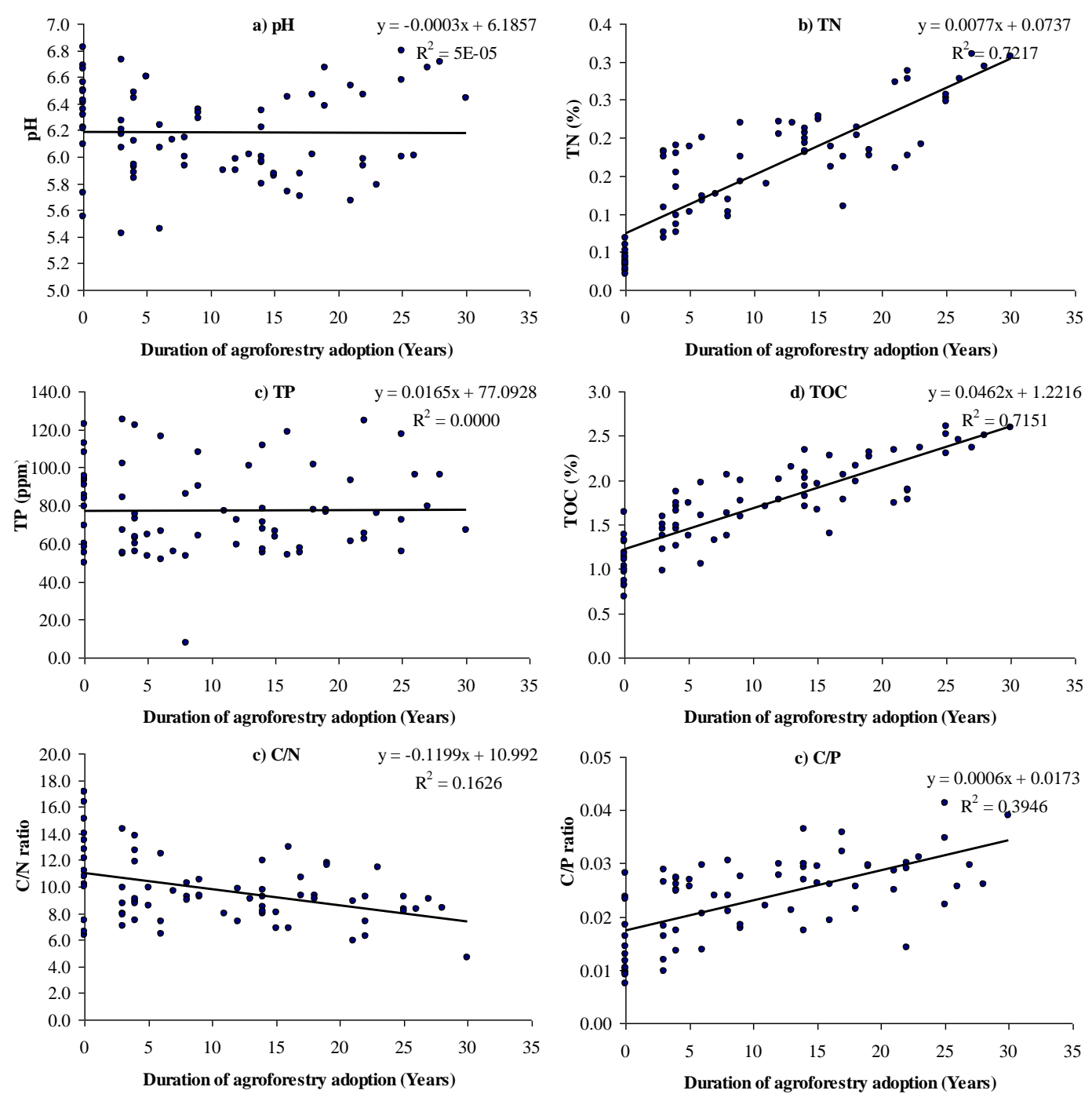

Figure 3: Variation in $\mathrm{pH}$, and concentration of $\mathrm{TN}, \mathrm{TP}, \mathrm{TOC}, \mathrm{C} / \mathrm{N}$ and $\mathrm{C} / \mathrm{P}$ ratios in the soils among farmers with different durations of agroforestry adoption 
The TP of the soil ranged from 8-125.4 ppm in agroforestry soils but was 50.03-122.7 ppm in soil without any agroforestry practice. The TP in soils for farmers with 1-5 years agroforestry practice was $77.61 \pm 24.21 \mathrm{ppm}$, those with 6-10 years practice it was $67.47 \pm 29.04 \mathrm{ppm}$, for farmers with 11-20 years of agroforestry practice it was $74.91 \pm 19.21 \mathrm{ppm}$ and those with 20 years of agroforestry practice the percent was $82.00 \pm 21.82 \mathrm{ppm}$. Further statistical analysis indicates that there was no significant difference in TP based on the duration of agroforestry practice $(P>0.05)$. These results indicate a similarity of TP between the adopters compared to the non adopters and showed no significant change with age and duration of agroforestry adoption. Similarity in the TP in the soils between adopters and non adopters of agroforestry could be due to lack of any phosphate fertilizers during cropping system. Leaves of the trees also rarely contribute to any $\mathrm{TP}$ addition in the soils, beside the soil could be low in phosphorus content as reported for several tropical soils (Roy et al., 2016; Maranguit et al., 2017; Meyer et al., 2018).

The TOC of the soil ranged from $0.98-2.60 \mathrm{ppm}$ in agroforestry soils but was lower at 0.69 $1.64 \mathrm{ppm}$ in soil without any agroforestry practice. The TOC in soils for farmers with 1-5 years agroforestry practice was $1.50 \pm 0.25 \mathrm{ppm}$, those with $6-10$ years practice it was $1.61 \pm$ $0.30 \mathrm{ppm}$, then among farmers with 11-20 years of agroforestry practice it was $1.97 \pm 0.25$ ppm and those with 20 years of agroforestry practice the percent was $2.26 \pm 0.32 \mathrm{ppm}$. Further statistical analysis indicates that there was a significant difference of TOC based on the duration of agroforestry practice $(P<0.05)$. The concentration of TOC was also determined to increase significantly with age of agroforestry adoption. Higher concentration of TOC in soils where agroforestry is practiced has been reported in several studies (Benbi et al., 2015; Bhaduri et al., 2017; Bayala et al., 2018; Lim et al., 2018). Trees have extensive root systems which can grow deep into the mineral soil. The root-derived $\mathrm{C}$ inputs are critical 
sources for the SOC pool in deeper soil horizons (Shi et al., 2013). Specifically, root-derived carbon $(\mathrm{C})$ is more likely to be stabilized in the soil by physico-chemical interactions with soil particles than shoot-derived C (Kukal \& Bawa, 2014). Similarly, in croplands, total root derived $\mathrm{C}$ contributed between 1.5 times to more than 3 times more $\mathrm{C}$ to SOC than shootderived C (Johnson et al., 2006). Thus, agroforestry systems store more C in deeper soil layers near trees than away from trees (Nair et al., 2015).

The $\mathrm{C} / \mathrm{N}$ ratio of the soil ranged from 4.66-14.32 ppm in agroforestry soils but was 6.39$17.16 \mathrm{ppm}$ in soil without any agroforestry practice. The $\mathrm{C} / \mathrm{N}$ in soils for farmers with 1-5 years agroforestry practice was $9.95 \pm 2.40 \mathrm{ppm}$, those with $6-10$ years practice it was $9.23 \pm$ $1.60 \mathrm{ppm}$, then among farmers with 11-20 years of agroforestry practice it was $9.31 \pm 1.74$ ppm and those with 20 years of agroforestry practice the range was $8.08 \pm 1.73 \mathrm{ppm}$. Further statistical analysis indicates that there was a significant difference in $\mathrm{C} / \mathrm{N}$ based on the duration of agroforestry practice $(P<0.05)$. The concentration of $\mathrm{C} / \mathrm{N}$ decreases significantly with age and duration of agroforestry adoption. The current results suggest that the net increase in carbon in the soil was less than the net increase in Nitrogen in the soil after long period of agroforestry practice. Higher concentration of Nitrogen relative to carbon in soils where agroforestry is practiced has been reported in several studies (Benbi et al., 2015; Bhaduri et al., 2017; Bayala et al., 2018; Lim et al., 2018). The accumulation of nitrogen in the soil may be added by leaf litter decomposition in addition to inorganic and organic fertilizers used during cultivation of food crops and therefore it is likely to increase at higher accumulation than nitrogen over a long period of time. The resulting enhanced tree and crop plant growth by subsequent increase in nitrogen $(\mathrm{N})$ nutrition may result in an increase in SOC sequestration (Ziter \& MacDougall, 2013). Similar, mixed plantings with N-fixing trees may cause higher biomass production and, thus, SOC sequestration and pools particularly in 
deeper soil horizons as $\mathrm{N}$ may promote humification rather than decay. Also, changes in microbial decomposer community composition under $\mathrm{N}$-fixing trees may result in greater retention of relatively stable SOC (Prescott, 2002). Aside from deep soil C inputs, another reason for the promotion of $\mathrm{C}$ sequestration in agroforestry systems is that tree roots have the potential to recover nutrients from below the crop rooting zone.

The C/P ratio of the soil ranged from 0.01-0.04 ppm in agroforestry soils but was 0.01-0.03 ppm in soil without any agroforestry practice. The C/P ratio in soils for farmers with 1-5 years agroforestry practice was $0.01 \pm 0.01 \mathrm{ppm}$, those with $6-10$ years practice it was $0.02 \pm$ $0.01 \mathrm{ppm}$, then among farmers with 11-20 years of agroforestry practice it was $0.02 \pm 0.01$ ppm and those with 20 years of agroforestry practice the percent was $0.03 \pm 0.01 \mathrm{ppm}$. Further statistical analysis indicates that there was a significant difference in $\mathrm{C} / \mathrm{P}$ ratio based on the duration of agroforestry practice $(P<0.05)$. The results show that the proportion of $\mathrm{C} / \mathrm{P}$ was significantly higher among the adopters compared to the non adopters and increased with increasing age of adoption. Increased proportion of $\mathrm{C} / \mathrm{P}$ in soil has been reported to occur in soils where agroforestry is practiced (Lu et al., 2015; Gurmessa et al., 2016; Kim et al., 2016; Atapattu et al., 2017; Bhatt et al., 2017). These results suggest that carbon accumulation in the soil increased at a higher rate than phosphorus. The low rate of TP accumulation in the soils could be due to lack of any phosphate fertilizers during cropping system. Leaves of the trees also rarely contribute to any TP addition in the soils, beside the soil could be low in phosphorus content as reported for several tropical soils (Roy et al., 2016; Maranguit et al., 2017; Meyer et al., 2018). 


\subsection{Exchangeable bases in the soil}

The concentration of exchangeable bases in the soils between the adopters and non adopters in Machakos County is shown in Table 3.

Table 3: Concentration of exchangeable bases in the soils between the adopters and non adopters in Machakos County

\begin{tabular}{lllll}
\hline Age of adoption & Potassium & Calcium & Magnesium & Sodium \\
\hline 0 & $0.96 \pm 0.14$ & $3.27 \pm 1.05$ & $5.91 \pm 0.29$ & $2.57 \pm 0.82$ \\
$1-5$ & $1.16 \pm 0.14$ & $3.39 \pm 1.17$ & $5.82 \pm 0.21$ & $2.88 \pm 0.93$ \\
$6-10$ & $0.89 \pm 0.14$ & $3.58 \pm 1.32$ & $6.37 \pm 0.24$ & $2.52 \pm 0.57$ \\
$11-20$ & $1.16 \pm 0.10$ & $3.99 \pm 1.00$ & $5.93 \pm 0.35$ & $2.68 \pm 0.74$ \\
$>20$ & $1.02 \pm 0.13$ & $4.02 \pm 0.46$ & $6.08 \pm 0.51$ & $3.51 \pm 0.89$ \\
ANOVA & & & & \\
F & 8.674 & 13.455 & 13.423 & 7.951 \\
df & 4 & 4 & 4 & 4 \\
P & 0.00242 & 0.0001 & 0.0001 & 0.0007 \\
\hline
\end{tabular}

The concentration of potassium in the soil ranged from 1.02-1.32 ppm in soil practising while in soils without such practices, potassium ranged from 0.83.-0.97 ppm. The potassium concentration in soils for farmers with 1-5 years agroforestry practice was $1.16 \pm 0.14 \mathrm{ppm}$, those with 6-10 years practice it was $0.89 \pm 0.14 \mathrm{ppm}$, then among farmers with 11-20 years of agroforestry practice it was $1.16 \pm 0.10 \mathrm{ppm}$ and those with 20 years of agroforestry practice the range was $1.02 \pm 0.13 \mathrm{ppm}$. Further statistical analysis indicates that there was a significant difference in potassium based on the duration of agroforestry practice $(P<0.05)$. 
The concentration of potassium in soils was higher among the adopters as compared to the non adopters and exhibited an increasing trend with increasing duration of agroforestry adoption (Figure 4). Higher potassium in soils practicing agroforestry has been reported in several other studies (Islam \& Weil, 2000; Celik, 2005; Lang et al., 2016; Atapattu et al., 2017; Mulyono et al., 2019). Higher available potassium in tree based systems may be due to nutrient rich litter of trees, which may have contributed to higher amount of potassium returned back to the soil in the form of litter (Clark et al., 1998). The increased potassium in soils could also be due to decomposition of organic matter in soil which is higher in soils practising agroforestry.
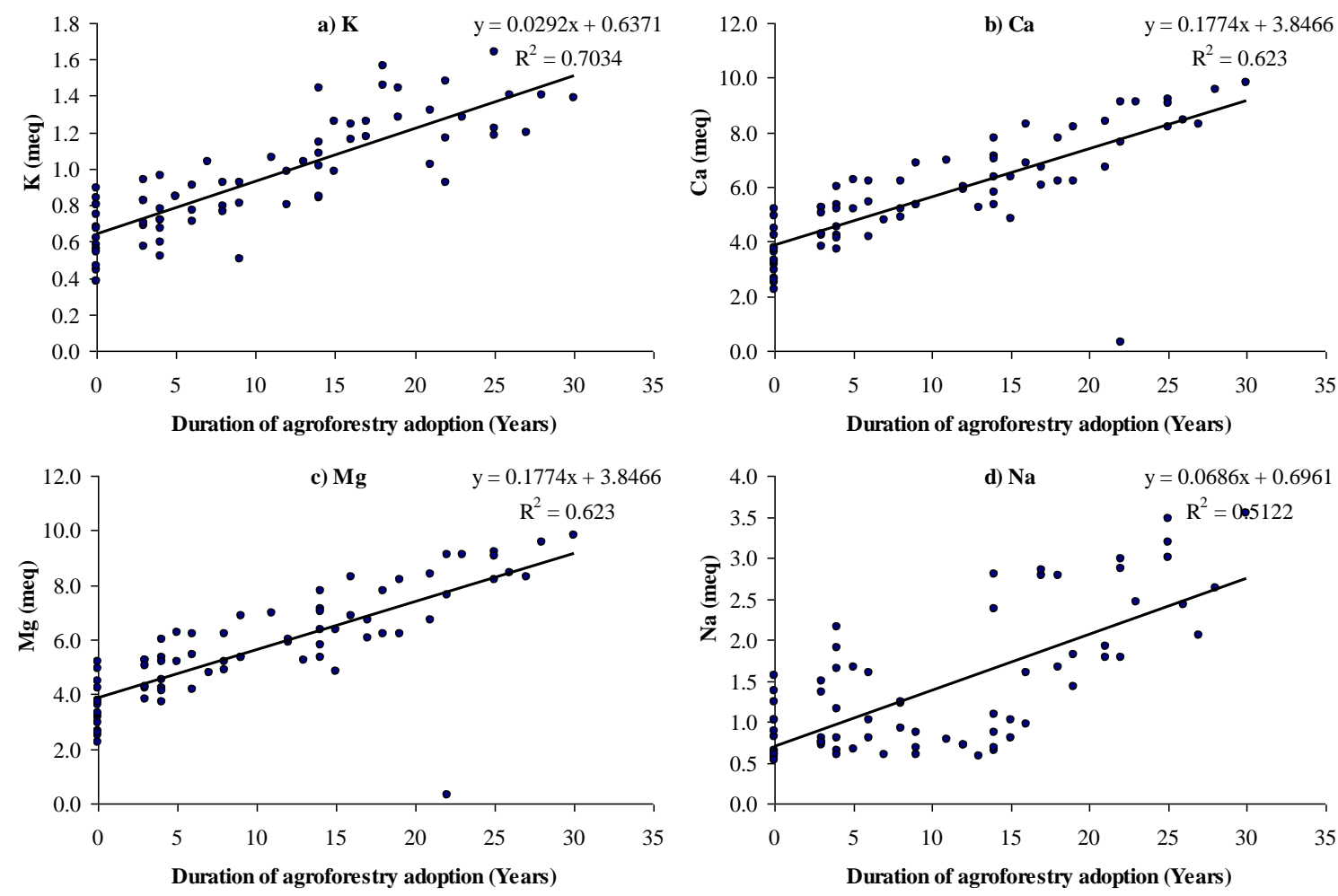

Figure 4: Variation in concentration of exchangeable bases in the soils among farmers with different durations of agroforestry adoption.

The calcium in the soil ranged from 2.8-5.4 ppm in soils where agroforestry was practiced but in soil without any agroforestry practice it was 2.5 to $3.2 \mathrm{ppm}$. The calcium concentration 
in the soils for farmers with $1-5$ years agroforestry practice was $3.39 \pm 1.17 \mathrm{ppm}$, those with 6-10 years practice it was $3.58 \pm 1.32 \mathrm{ppm}$, then among farmers with 11-20 years of agroforestry practice it was $3.99 \pm 1.00 \mathrm{ppm}$ and those with 20 years of agroforestry practice the range was $4.02 \pm 0.46$. Further statistical analysis indicates that there was a significant difference in Calcium based on the duration of agroforestry practice $(P<0.05)$. Concentration of calcium in the soil was higher among the adopters as compared to the non adopters and increased with increasing duration of agroforestry adoption. Increasing calcium in soils due to agroforestry has been reported in several studies (Behera \& Shukla, 2015; Ngo-Mbogba et al., 2015; Sharma et al., 2016; Prakash et al., 2018; Mulyono et al., 2019). The increase in calcium in the soil could be due to addition of soil additives such as lime during tillage operation.

The magnesium in the soil was low in soils devoid of agroforestry practices (5.72.-5.99 ppm) but was higher in soils practising agroforestry (5.79-6.32 ppm). The Mg content in soils for farmers with 1-5 years agroforestry practice was $5.82 \pm 0.21 \mathrm{ppm}$, those with 6-10 years practice it was $6.37 \pm 0.24 \mathrm{ppm}$, for $11-20$ years it was $5.93 \pm 0.35 \mathrm{ppm}$ and those with 20 years of agroforestry practice the range was $6.08 \pm 0.51$. Further statistical analysis indicates that there was a significant difference in $\mathrm{Mg}$ based on the duration of agroforestry practice $(P$ $<0.05)$. The concentration of $\mathrm{Mg}$ in the soil was higher among the adopters as compared to the non adopters and increased with increasing duration of agroforestry adoption. These studies concur with those of those of who showed a significant increase in $\mathrm{Mg}$ in soil is associated with agroforestry (Bhatt et al., 2016; da Cunha Salim et al., 2018; de Freitas et al., 2018; Mulyono et al., 2019). Magnesium is absorbed as the $\mathrm{Mg}^{2+}$ ion and is mobile in plants, moving from the older to the younger leaves (Tongkaemkaew et al., 2018) and therefore likely to increased in areas adopting agroforestry trees. Magnesium can also be increased in 
the soil due to liming which may not raise soil $\mathrm{pH}$ (Solanki, 2017). Therefore higher Mg content in the soils with a constant $\mathrm{pH}$ could have signalled that lime was the main sources of $\mathrm{Mg}$ in the soil.

The sodium in the soil without agroforestry practice was $2.54-2.66 \mathrm{ppm}$ while in soil practising agroforestry it was $2.56-3.63 \mathrm{ppm}$. Sodium content in soils for farmers with 1-5 years agroforestry practice was $2.88 \pm 0.93 \mathrm{ppm}$, those with $6-10$ years practice it was $2.52 \pm$ $0.57 \mathrm{ppm}$, then among farmers with 11-20 years of agroforestry practice it was $2.68 \pm 0.74$ ppm and those with 20 years of agroforestry practice the percent was $3.51 \pm 0.89$. Further statistical analysis indicates that there was a significant difference in $\mathrm{Na}$ based on the duration of agroforestry practice $(P<0.05)$. Sodium in the soil was higher among the adopters as compared to the non adopters and increased with increasing duration of agroforestry adoption. These studies concur with other studies which found a significant increase in sodium during agroforestry (Githae et al., 2011; Lagerlöf et al., 2014; Bayala et al., 2018; Corbeels et al., 2019). The possible application of organic residues during agriculture could be sources of sodium and the use of organic manure in the soils could have increased sodium in the soil.

The foregoing observations regarding higher exchangeable bases in the agroforestry soils, may suggest that these nutrients are being taken up mostly from the zone of higher tree root density and may be accumulating in tree biomass (Alfaia, 2004). Moreover, it seems these exchangeable bases may be considered limiting nutrient for plant growth in the region and therefore plants were able to extract them from the soil and accumulate them above ground or within the soils (Diehl et al., 2008). 


\subsection{Micro-nutrients in the soils}

The overall concentrations of micro-nutrients of the soils between the adopters and non adopters in Machakos County are shown in Table 4 while the trends in micro-nutrients with age and duration of agroforestry are provided in Figure 5.

Table 4: Concentrations of micro-nutrients of the soils between the adopters and non adopters in Machakos County

\begin{tabular}{lllll}
\hline Age brackets & Manganese & Copper & Iron & Zinc \\
\hline 0 & $1.32 \pm 0.03$ & $8.62 \pm 3.93$ & $350.57 \pm 85.22$ & $32.20 \pm 5.54$ \\
$1-5$ & $1.33 \pm 0.03$ & $8.80 \pm 1.40$ & $352.76 \pm 98.93$ & $33.64 \pm 9.31$ \\
$6-10$ & $1.33 \pm 0.04$ & $8.01 \pm 1.17$ & $521.55 \pm 105.22$ & $51.93 \pm 9.72$ \\
$10-20$ & $1.38 \pm 0.04$ & $12.32 \pm 3.27$ & $503.76 \pm 90.44$ & $37.09 \pm 6.22$ \\
$>20$ & $1.36 \pm 0.05$ & $12.77 \pm 2.07$ & $514.73 \pm 61.65$ & $40.58 \pm 11.62$ \\
ANOVA & & & & \\
F & 7.6145 & 6.675 & 6.9923 & 4.7721 \\
df & 4 & 4 & 4 & 4 \\
P value & 0.0004 & 0.0012 & 0.0002 & 0.0022 \\
\hline
\end{tabular}

The Manganese $(\mathrm{Mn})$ of the soil ranged from 1.32-1.39 ppm in soils practicing agroforestry, but was 1.30-1.32 ppm in soil without any agroforestry practice. The Mn in soils for farmers with 1-5 years agroforestry practice was $1.33 \pm 0.03 \mathrm{ppm}$, those with $6-10$ years practice it was $1.33 \pm 0.04 \mathrm{ppm}$, then among farmers with 11-20 years of agroforestry practice it was $1.38 \pm 0.04 \mathrm{ppm}$ and those with 20 years of agroforestry practice the percent was $1.36 \pm 0.05$ ppm. Further statistical analysis indicates that there was a significant difference in 
Manganese based on the duration of agroforestry practice $(P<0.05)$. The concentration of Mn increased with age and duration of adoption of agroforestry. These studies concur with those of those of who showed a significant increase in $\mathrm{Mn}$ in soil is associated with agroforestry (Bhatt et al., 2016; da Cunha Salim et al., 2018; de Freitas et al., 2018; Mulyono et al., 2019). The major pool of manganese in soils originates from crustal sources, with other sources including direct atmospheric deposition, wash-off from plant and other surfaces, leaching from plant tissues, and the shedding or excretion of material such as leaves, dead plant and animal material, and animal excrement (Parjono et al., 2019). Therefore it is more likely that Mn sources during agroforestry was from wash off from plants an leachates from plant tissues as well as shedding of leaves, dead plants and livestock materials.
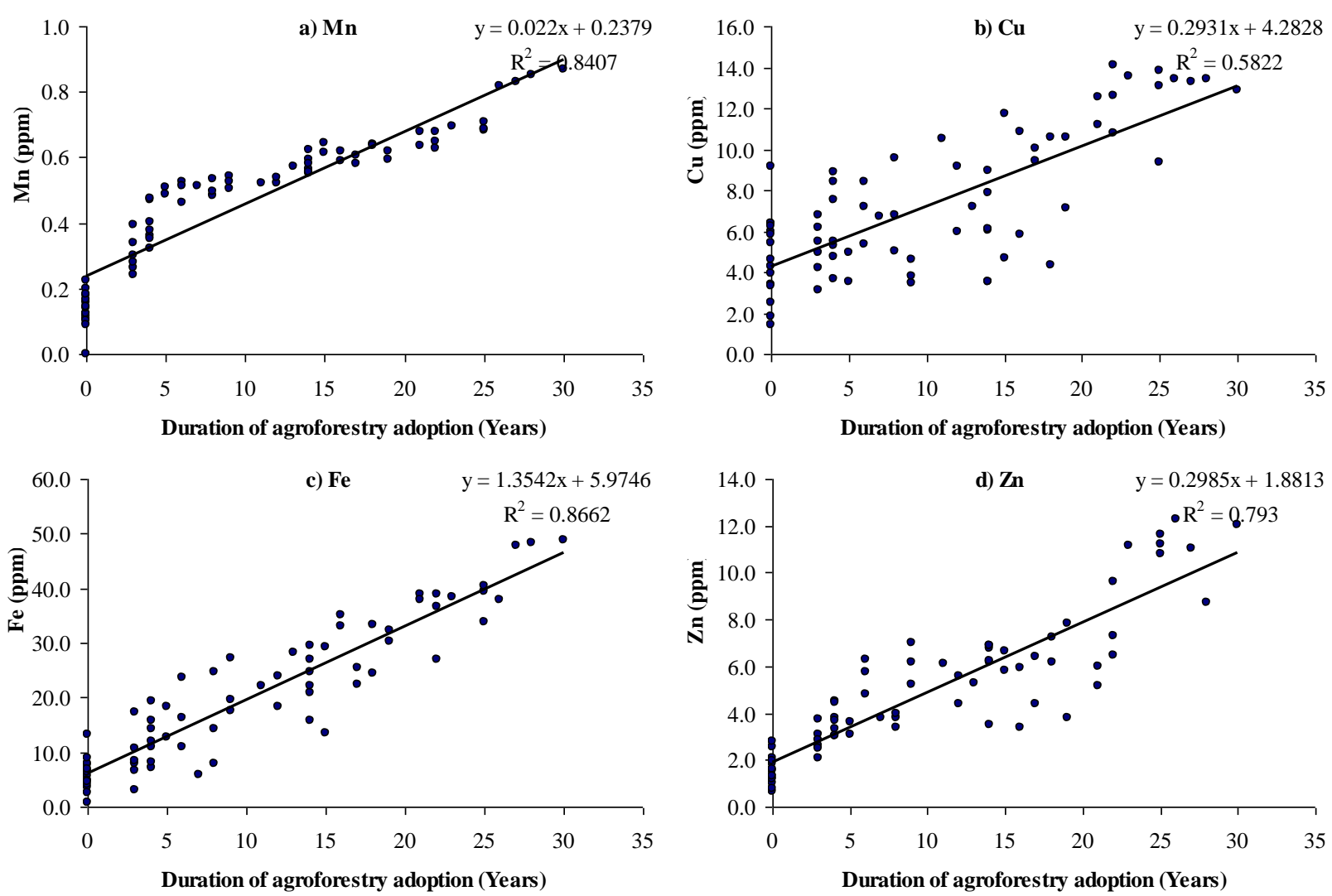

Figure 5: Variation in micro nutrients in the soils among farmers with different durations of agroforestry adoption. 
The concentration of copper in the soil ranged from $8.56-10.70 \mathrm{ppm}$ in soils without agroforestry but was $8.82-12.98 \mathrm{ppm}$ in soil whose owners practice agroforestry. The $\mathrm{Cu}$ in soils for farmers with 1-5 years agroforestry practice was $8.80 \pm 1.40 \mathrm{ppm}$, those with $6-10$ years practice $\mathrm{Cu}$ was $8.01 \pm 1.17 \mathrm{ppm}$, and 11-20 years of agroforestry practice it was 12.32 $\pm 3.27 \mathrm{ppm}$ and those with 20 years of agroforestry practice the percent was $12.77 \pm 2.07$ ppm. Further statistical analysis shows that there was a significant difference in copper relative to the duration of agroforestry practice $(P<0.05)$. The concentration of copper increased with age and duration of adoption of agroforestry. These studies concur with those of those of who showed a significant increase in copper in soils is associated with agroforestry (Lambert \& Ozioma, 2012; Uthappa et al., 2015; Sistla et al., 2016; Dhaliwal et al., 2019; Prasad et al., 2019). Copper present as an impurity in silicate minerals or carbonates (Gautam et al., 2017). In some soils, organic matter and soil $\mathrm{pH}$ influence copper availability where copper availability increases as organic matter in soil increases since organic matter binds copper from the free state and liberate the copper when it decomposes (Mounissamy et al., 2017). Therefore the high organic matter content can be the main source of copper in agroforestry soils.

In the soils, practice of agroforestry elevated iron from 355 to 527 ppm compared to 350 to $278 \mathrm{ppm}$ in soils devoid of agroforestry. The iron concentration in soils for farmers with 1-5 years agroforestry practice was $352.76 \pm 98.93 \mathrm{ppm}$, those with 6-10 years practice it was $521.55 \pm 105.22 \mathrm{ppm}$, then among farmers with $11-20$ years of agroforestry practice it was $503.76 \pm 90.44 \mathrm{ppm}$ and those with 20 years of agroforestry practice the concentration was $514.73 \pm 61.65 \mathrm{ppm}$. There was a significant difference in iron based on the duration of agroforestry practice $(P<0.05)$. Further statistical analysis indicates that there was a significant difference in iron based on the duration of agroforestry practice $(P<0.05)$. 
Increased iron concentration with age and duration of agroforestry has been reported in other studies as well (Lorenz \& Lal, 2014; Schwab et al., 2015; Abreu et al., 2016; Wang et al., 2017; Salgado et al., 2019). Most of the iron in soil are found in silicate minerals or iron oxides and hydroxides, forms that are not readily available for plant use (Pandey et al., 2000; De Souza et al., 2012). Most of the iron are derived from organic matter and degradation of the organic matter pool renders iron readily available in the soils (Yadav et al., 2011). Practices that increase levels of soil organic matter, such as adding manure to soil during agroforestry therefore seems to result in increased iron content in the soils. Iron can also have been increased by spraying of the plants grown during agroforestry with supplemental iron containing fertilizers.

The zinc in the soil ranged from 31.4 to $33.2 \mathrm{ppm}$ in soils with no form of agroforestry soils but was $33.442 .6 \mathrm{ppm}$ in soil practicing agroforestry. The zinc in soils for farmers with 1-5 years agroforestry practice was $33.64 \pm 9.31 \mathrm{ppm}$, those with $6-10$ years practice it was 51.93 $\pm 9.72 \mathrm{ppm}$, then among farmers with 11-20 years of agroforestry practice it was $37.09 \pm 6.22$ ppm and those with 20 years of agroforestry practice the concentration was $40.58 \pm 11.62$ ppm. Further statistical analysis indicates that there was a significant difference in zinc based on the duration of agroforestry practice $(P<0.05)$. Further statistical analysis indicates that there was a significant difference in zinc based on the duration of agroforestry practice $(P<$ 0.05). The concentration of zinc increased with age and duration of agroforestry adoption. These studies concur with those of those of who showed a significant increase in zinc in soil is associated with agroforestry (Bhatt et al., 2016; da Cunha Salim et al., 2018; de Freitas et al., 2018; Mulyono et al., 2019; Parveen et al., 2019). Zinc can be increased in the soil by application of fertilizers containing zinc, of which the most common are zinc chelates, zinc Sulfate and zinc oxide which common in most fertilizers formulation (Meena et al., 
2019). It has also been reported that high levels of phosphorus found in several phosphate fertilizers (e.g. DAP) may increase the concentration of zinc in the soil by interfering with its metabolism in plants and help in the precipitation of zinc in soil (Bhaduri et al., 2017; Lenci et al., 2018; Sarabia et al., 2020).

\section{Conclusion}

Analysis of the physical attributes of the soils indicate that proportion of sand particles was higher among non adopters compared to adopters of agroforestry while the proportion of silt and bulk density in the soil was higher among the adopters. In terms of chemical properties, the study established that $\mathrm{TN}, \mathrm{TOC}, \mathrm{Ca}, \mathrm{Mg}, \mathrm{Mn}, \mathrm{Cu}, \mathrm{Fe}, \mathrm{Zn}$ and $\mathrm{C} / \mathrm{N}$ ratio were higher in soils where agroforestry was being practiced but soil $\mathrm{pH}$, total phosphorus, potassium, and sodium showed similarity between soils practicing agroforestry and those without the practice. Overall physical and chemical attributes in the soil appeared to improve with increasing duration of agroforestry adoption. The study recommends adoption of agroforestry and longer period of practices to improve and enhance physico-chemical soil quality parameters for higher agricultural productivity in the tropical regions of Sub Saharan Africa.

\section{Acknowledgement}

The authors sincerely thank the Kenya Organization for Environmental Education (KOEE) through Faith Based Climate Change Education for Sustainable Development (FBCCESD) for their financial contribution to this study. We appreciate the Kenya Agricultural and Livestock Research Organization (KALRO) for training of research assistants, field data collection and analysis. We also thank staff of Kenya Forest Service (KFS) for their assistance in identifying conservation groups for this study. Sincere gratitude must go to the local community members who provided the critical data. 


\section{References}

Abbas, F., Hammad, H.M., Fahad, S., Cerdà, A., Rizwan, M., Farhad, W., Ehsan, S., Bakhat, H.F. (2017). Agroforestry: a sustainable environmental practice for carbon sequestration under the climate change scenarios-a review. Environmental Science and Pollution Research. 24, 11177-11191.

Abreu, S.A.H., Arruda, E.M., Barros, L.R., de Almeida, R.F., Maranhão, D.D.C., da Silva, V.L., de Melo, C., Neto, S., Flores, R.A., Calil, F.N. (2016). Chemical attributes of the soil in agroforestry systems subjected to organic fertilizations. African Journal of Agricultural Research. 11, 2378-2388.

Akdemir, E., Anderson, S.H., Udawatta, R.P. (2016). Influence of agroforestry buffers on soil hydraulic properties relative to row crop management. Soil Science. 181, 368-376.

Alam, M., Furukawa, Y., Harada, K. (2010). Agroforestry as a sustainable landuse option in degraded tropical forests: a study from Bangladesh. Environment, development and sustainability. 12, 147-158.

Alfaia, S.S., Ribeiro, G.A., Nobre, A.D., Luizão, R.C. and Luizão, F.J., 2004. (2004). Evaluation of soil fertility in smallholder agroforestry systems and pastures in western Amazonia. Agriculture, Ecosystems \& Environment. 102, 409-414.

Atangana, A., Khasa, D., Chang, S., Degrande, A. (2013). Tropical agroforestry. Springer Science \& Business Media.

Atangana, A., Khasa, D., Chang, S., Degrande, A. (2014). Major agroforestry systems of the humid tropics, Tropical agroforestry. Springer, pp. 49-93.

Atapattu, A., Senarathne, S., Raveendra, S., Egodawatte, W., Mensah, S. (2017). Effect of short term agroforestry systems on soil quality in marginal coconut lands in Sri Lanka. Agric Res J. 54, 324-328.

Bayala, J., Kalinganire, A., Sileshi, G., Tondoh, J. (2018). Soil organic carbon and nitrogen in agroforestry systems in Sub-Saharan Africa: a review, Improving the Profitability, Sustainability and Efficiency of Nutrients Through Site Specific Fertilizer Recommendations in West Africa Agro-Ecosystems. Springer, pp. 51-61.

Behera, L., Nayak, M.R., Patel, D., Mehta, A., Sinha, S.K., Gunaga, R. (2015). Agroforestry practices for physiological amelioration of salt aff ected soils. Journal of Plant Stress Physiology. 13-18. 
Behera, S.K., Shukla, A.K. (2015). Spatial distribution of surface soil acidity, electrical conductivity, soil organic carbon content and exchangeable potassium, calcium and magnesium in some cropped acid soils of India. Land Degradation \& Development. 26, 71-79.

Béliveau, A., Lucotte, M., Davidson, R., Paquet, S., Mertens, F., Passos, C.J., Romana, C.A. (2017). Reduction of soil erosion and mercury losses in agroforestry systems compared to forests and cultivated fields in the Brazilian Amazon. Journal of environmental management. 203, 522-532.

Benbi, D.K., Brar, K., Toor, A.S., Singh, P. (2015). Total and labile pools of soil organic carbon in cultivated and undisturbed soils in northern India. Geoderma. 237, 149-158.

Benjamin, E.O., Sauer, J. (2018). The cost effectiveness of payments for ecosystem services-Smallholders and agroforestry in Africa. Land use policy. 71, 293-302.

Beyene, A.D., Mekonnen, A., Randall, B., Deribe, R. (2019). Household Level Determinants of Agroforestry Practices Adoption in Rural Ethiopia. Forests, Trees and Livelihoods. $1-20$.

Bhaduri, D., Pramanik, P., Ghosh, S., Chakraborty, K., Pal, S. (2017). Agroforestry for improving soil biological health. Agroforestry for increased production and livelihood security. New India Publishing Agency, New Delhi. 465-491.

Bhatt, B., Parmar, B., Bordoloi, L., Bhattacharyya, R. (2016). Impacts of Agroforestry Systems on Soil and Nutrient Conservation in the Eastern Himalayas, India. International Journal of Bio-Resource \& Stress Management. 7.

Bhatt, H., Husain, M., Rathore, J.P., Sah, V. (2017). Bioremediation of problematic soils through Agroforestry practices. Journal of Pharmacognosy and Phytochemistry. 6, 2044-2048.

Bünemann, E.K., Bongiorno, G., Bai, Z., Creamer, R.E., De Deyn, G., de Goede, R., Fleskens, L., Geissen, V., Kuyper, T.W., Mäder, P. (2018). Soil quality-A critical review. Soil Biology and Biochemistry. 120, 105-125.

Buyer, J.S., Baligar, V.C., He, Z., Arévalo-Gardini, E. (2017). Soil microbial communities under cacao agroforestry and cover crop systems in Peru. Applied soil ecology. 120, 273-280.

Cardinael, R., Chevallier, T., Barthès, B.G., Saby, N.P., Parent, T., Dupraz, C., Bernoux, M., Chenu, C. (2015). Impact of alley cropping agroforestry on stocks, forms and spatial 
distribution of soil organic carbon-A case study in a Mediterranean context. Geoderma. 259, 288-299.

Cardinael, R., Chevallier, T., Cambou, A., Béral, C., Barthès, B.G., Dupraz, C., Durand, C., Kouakoua, E., Chenu, C. (2017). Increased soil organic carbon stocks under agroforestry: a survey of six different sites in France. Agriculture, Ecosystems \& Environment. 236, 243-255.

Catacutan, D., Van Noordwijk, M., Nguyen, T., Öborn, I., Mercado, A. (2017). Agroforestry: contribution to food security and climate-change adaptation and mitigation in Southeast Asia. White Paper. Bogor, Indonesia: World Agroforestry Centre (ICRAF) Southeast Asia Regional Program.

Celik, I. (2005). Land-use effects on organic matter and physical properties of soil in a southern Mediterranean highland of Turkey. Soil and Tillage Research. 83, 270-277.

Chaudhari, P.R., Ahire, D.V., Ahire, V.D., Chkravarty, M., Maity, S. (2013). Soil bulk density as related to soil texture, organic matter content and available total nutrients of Coimbatore soil. International Journal of Scientific and Research Publications. 3, 18.

Clark, M.S., Horwath, W.R., Shennan, C., Scow, K.M. (1998). Changes in soil chemical properties resulting from organic and low-input farming practices. Agronomy Journal. 90, 662-671.

Corbeels, M., Cardinael, R., Naudin, K., Guibert, H., Torquebiau, E. (2019). The 4 per 1000 goal and soil carbon storage under agroforestry and conservation agriculture systems in sub-Saharan Africa. Soil and Tillage Research. 188, 16-26.

da Cunha Salim, M.V., Miller, R.P., Ticona-Benavente, C.A., van Leeuwen, J., Alfaia, S.S. (2018). Soil fertility management in indigenous homegardens of Central Amazonia, Brazil. Agroforestry systems. 92, 463-472.

Dalemans, F., Muys, B., Maertens, M. (2018). Adoption of agroforestry-based biofuel systems in South India.

de Freitas, W.K., Portz, A., de Carvalho Peres, A.A., Tarré, R.M., de Melo Campos, M. (2018). Soil nutrient content and plant phytosociology in agroforestry systems of the Rio de Janeiro State highlands, Brazil. Acta Scientiarum. Biological Sciences. 40, 1-8.

De Souza, H.N., de Goede, R.G., Brussaard, L., Cardoso, I.M., Duarte, E.M., Fernandes, R.B., Gomes, L.C., Pulleman, M.M. (2012). Protective shade, tree diversity and soil 
properties in coffee agroforestry systems in the Atlantic Rainforest biome. Agriculture, Ecosystems \& Environment. 146, 179-196.

Deng, B., Tammeorg, P., Luukkanen, O., Helenius, J., Starr, M. (2017). Effects of Acacia seyal and biochar on soil properties and sorghum yield in agroforestry systems in South Sudan. Agroforestry systems. 91, 137-148.

Desta, K.N., Lisanenwork, N., Muktar, M. (2018). Physico-chemical properties of soil under the canopies of Faidherbia albida (Delile) A. Chev and Acacia tortilis (Forssk.) Hayen in park land agroforestry system in Central Rift Valley, Ethiopia. Journal of Horticulture and Forestry. 10, 1-8.

Dhaliwal, S.S., Naresh, R.K., Walia, M.K., Gupta, R.K., Mandal, A., Singh, R. (2019). Longterm effects of intensive rice-wheat and agroforestry based cropping systems on build-up of nutrients and budgets in alluvial soils of Punjab, India. Archives of Agronomy and Soil Science. 1-13.

Diehl, P., Mazzarino, M.J., Fontenla, S. (2008). Plant limiting nutrients in AndeanPatagonian woody species: effects of interannual rainfall variation, soil fertility and mycorrhizal infection. Forest Ecology and Management. 225, 2973-2980.

Dollinger, J., Jose, S. (2018). Agroforestry for soil health. Agroforestry systems. 92, 213-219.

Feliciano, D., Ledo, A., Hillier, J., Nayak, D.R. (2018). Which agroforestry options give the greatest soil and above ground carbon benefits in different world regions? Agriculture, ecosystems \& environment. 254, 117-129.

Fleming, A., O’Grady, A.P., Mendham, D., England, J., Mitchell, P., Moroni, M., Lyons, A. (2019). Understanding the values behind farmer perceptions of trees on farms to increase adoption of agroforestry in Australia. Agronomy for Sustainable Development. 39, 9.

Franzel, S., Coe, R., Cooper, P., Place, F., Scherr, S. (2001). Assessing the adoption potential of agroforestry practices in sub-Saharan Africa. Agricultural systems. 69, 37-62.

Gama-Rodrigues, E.F., Nair, P.R., Nair, V.D., Gama-Rodrigues, A.C., Baligar, V.C., Machado, R.C. (2010). Carbon storage in soil size fractions under two cacao agroforestry systems in Bahia, Brazil. Environmental management. 45, 274-283.

García de Jalón, S., Burgess, P.J., Graves, A., Moreno, G., McAdam, J., Pottier, E., Novak, S., Bondesan, V., Mosquera-Losada, R., Crous-Durán, J. (2017). How is agroforestry perceived in Europe? An assessment of positive and negative aspects by stakeholders. 
Gautam, D.K., Bajracharya, R.M., Sitaula, B.K. (2017). Effects of biochar and farm yard manure on soil properties and crop growth in an agroforestry system in the Himalaya. Sustainable Agriculture Research. 6.

Githae, E.W., Gachene, C.K., Njoka, J.T. (2011). Soil physicochemical properties under Acacia senegal varieties in the dryland areas of Kenya. African Journal of Plant Science. 5, 475-482.

Gurmessa, B., Demessie, A., Lemma, B. (2016). Dynamics of soil carbon stock, total nitrogen, and associated soil properties since the conversion of Acacia woodland to managed pastureland, parkland agroforestry, and treeless cropland in the Jido Komolcha District, southern Ethiopia. Journal of Sustainable Forestry. 35, 324-337.

Hairiah, K., Sulistyani, H., Suprayogo, D., Purnomosidhi, P., Widodo, R.H., Van Noordwijk, M. (2006). Litter layer residence time in forest and coffee agroforestry systems in Sumberjaya, West Lampung. Forest ecology and management. 224, 45-57.

Hasselquist, N.J., Benegas, L., Roupsard, O., Malmer, A., Ilstedt, U. (2018). Canopy cover effects on local soil water dynamics in a tropical agroforestry system: Evaporation drives soil water isotopic enrichment. Hydrological processes. 32, 994-1004.

Hassink, J. (1997). The capacity of soils to preserve organic C and $\mathrm{N}$ by their association with clay and silt particles. Plant and soil. 191, 77-87.

Hewins, D.B., Sinsabaugh, R.L., Archer, S.R., Throop, H.L. (2017). Soil-litter mixing and microbial activity mediate decomposition and soil aggregate formation in a sandy shrub-invaded Chihuahuan Desert grassland. Plant ecology. 218, 459-474.

Isaac, M.E., Borden, K.A. (2019). Nutrient acquisition strategies in agroforestry systems. Plant and Soil. 1-19.

Islam, K.R., Weil, R.R. (2000). Land use effects on soil quality in a tropical forest ecosystem of Bangladesh. Agriculture, Ecosystems \& Environment. 79, 9-16.

Johnson, J.-F., Allmaras, R., Reicosky, D. (2006). Estimating source carbon from crop residues, roots and rhizodeposits using the national grain-yield database. Agronomy journal. 98, 622-636.

Kar, S., Pant, K., Chandel, A., Roshanzada, S. (2019). Trend of soil parameters under different spacings of Grewia based agroforestry system in the mid hill zones of Himachal Pradesh. IJCS. 7, 1904-1907.

Karuma, A., Gachene, C.K., Gicheru, P., Mwang'ombe, A.W., Mwangi, H., Clavel, D., Verhagen, J., Von Kaufmann, R., Francis, J., Ekaya, W. (2011). Effects of legume 
cover crop and sub-soiling on soil properties and maize (Zea mays L) growth in semi arid area of machakos District, Kenya. Tropical and Subtropical Agroecosystems. 14, 237-243.

Kenya National Bureau of Statistics. (2010). Population census results of Kenya by the year 2009. Government Printers: Kairobi, Kenya. http://www.afdevinfo.com/htmlreports/org/org_33469.html.

Kim, D.-G., Terefe, B., Girma, S., Kedir, H., Morkie, N., Woldie, T.M. (2016). Conversion of home garden agroforestry to crop fields reduced soil carbon and nitrogen stocks in Southern Ethiopia. Agroforestry systems. 90, 251-264.

Kukal, S., Bawa, S. (2014). Soil organic carbon stock and fractions in relation to land use and soil depth in the degraded Shiwaliks hills of lower Himalayas. Land Degradation \& Development. 25, 407-416.

Kuyah, S., Öborn, I., Jonsson, M. (2017). Regulating ecosystem services delivered in agroforestry systems, Agroforestry. Springer, pp. 797-815.

Lagerlöf, J., Adolfsson, L., Börjesson, G., Ehlers, K., Vinyoles, G.P., Sundh, I. (2014). Landuse intensification and agroforestry in the Kenyan highland: impacts on soil microbial community composition and functional capacity. Applied soil ecology. 82, 93-99.

Lambert, O., Ozioma, A.F. (2012). Adoption of improved agroforestry technologies among contact farmers in Imo State, Nigeria. Asian journal of agriculture and rural development. 2, 1-9.

Lang, M., Li, P., Han, X., Qiao, Y., Miao, S. (2016). Gross nitrogen transformations in black soil under different land uses and management systems. Biology and fertility of soils. 52, 233-241.

Leakey, R.R., Tchoundjeu, Z., Schreckenberg, K., Shackleton, S.E., Shackleton, C.M. (2005). Agroforestry tree products (AFTPs): targeting poverty reduction and enhanced livelihoods. International Journal of Agricultural Sustainability. 3, 1-23.

Lenci, L., de Souza, E., Mascarenhas, A., Tsukamoto Filho, A.d.A., Soares, G.d.S. (2018). Phytosociological aspects and soil quality indicators in agroforestry systems. Nativa: Pesquisas Agrárias e Ambientais. 6, 745-753.

Li, J., Zhang, H., Chen, Q., Zhou, H. (2015). An analysis of soil fractal dimension in a sloping hedgerow agroforestry system in the Three Gorges Reservoir Area, China. Agroforestry systems. 89, 983-990. 
Lim, S.-S., Baah-Acheamfour, M., Choi, W.-J., Arshad, M.A., Fatemi, F., Banerjee, S., Carlyle, C.N., Bork, E.W., Park, H.-J., Chang, S.X. (2018). Soil organic carbon stocks in three Canadian agroforestry systems: From surface organic to deeper mineral soils. Forest ecology and management. 417, 103-109.

Ling, Q., Gao, X., Zhao, X., Huang, J., Li, H., Li, L., Sun, W., Wu, P. (2017). Soil water effects of agroforestry in rainfed jujube (Ziziphus jujube Mill.) orchards on loess hillslopes in Northwest China. Agriculture, Ecosystems \& Environment. 247, $343-$ 351.

Liu, C., Jin, Y., Liu, C., Tang, J., Wang, Q., Xu, M. (2018). Phosphorous fractions in soils of rubber-based agroforestry systems: Influence of season, management and stand age. Science of the Total Environment. 616, 1576-1588.

Lorenz, K., Lal, R. (2014). Soil organic carbon sequestration in agroforestry systems. A review. Agronomy for Sustainable Development. 34, 443-454.

Lu, S., Meng, P., Zhang, J., Yin, C., Sun, S. (2015). Changes in soil organic carbon and total nitrogen in croplands converted to walnut-based agroforestry systems and orchards in southeastern Loess Plateau of China. Environmental monitoring and assessment. 187, 688.

Maranguit, D., Guillaume, T., Kuzyakov, Y. (2017). Land-use change affects phosphorus fractions in highly weathered tropical soils. Catena. 149, 385-393.

McAdam, J., Curran, E. (2018). Adoption of Agroforestry Options in Land Use Policy Measures in Northern and Southern Ireland. Adoption of agroforestry options in land use policy measures in Northern and Southern Ireland., 78-81.

Meena, S.S., Srivastava, A., Singh, V., Gangwar, S., Kumar, V. (2019). Effect of manure and fertilizer on chemical properties of soil in agroforestry and rice-wheat cropping systems under open field condition. IJCS. 7, 3720-3727.

Meijer, S.S., Catacutan, D., Ajayi, O.C., Sileshi, G.W., Nieuwenhuis, M. (2015). The role of knowledge, attitudes and perceptions in the uptake of agricultural and agroforestry innovations among smallholder farmers in sub-Saharan Africa. International Journal of Agricultural Sustainability. 13, 40-54.

Meyer, N., Welp, G., Rodionov, A., Borchard, N., Martius, C., Amelung, W. (2018). Nitrogen and phosphorus supply controls soil organic carbon mineralization in tropical topsoil and subsoil. Soil Biology and Biochemistry. 119, 152-161. 
Montagnini, F., Metzel, R. (2017). The contribution of agroforestry to sustainable development goal 2: end hunger, achieve food security and improved nutrition, and promote sustainable agriculture, Integrating landscapes: Agroforestry for biodiversity conservation and food sovereignty. Springer, pp. 11-45.

Mora-Vallejo, A., Claessens, L., Stoorvogel, J., Heuvelink, G.B. (2008). Small scale digital soil mapping in Southeastern Kenya. Catena. 76, 44-53.

Mounissamy, V.C., Kundu, S., Selladurai, R., Saha, J.K., Biswas, A.K., Adhikari, T., Patra, A.K. (2017). Effect of Soil Amendments on Microbial Resilience Capacity of Acid Soil Under Copper Stress. Bulletin of environmental contamination and toxicology. 99, 625-632.

Mulyono, A., Suriadikusumah, A., Harriyanto, R., Djuwansah, M.R. (2019). Soil Quality under Agroforestry Trees Pattern in Upper Citarum Watershed, Indonesia. Journal of Ecological Engineering. 20, 203-213.

Nair, R., Mehta, C., Sharma, S. (2015). Carbon sequestration in soils-A Review. Agricultural Reviews. 36.

Nasielski, J., Furze, J.R., Tan, J., Bargaz, A., Thevathasan, N.V., Isaac, M.E. (2015). Agroforestry promotes soybean yield stability and N 2-fixation under water stress. Agronomy for sustainable development. 35, 1541-1549.

Newaj, R., Chaturvedi, O., Handa, A. (2016). Recent development in agroforestry research and its role in climate change adaptation and mitigation. Indian J. Agrofor. 18, 1-9.

Ngo-Mbogba, M., Yemefack, M., Nyeck, B. (2015). Assessing soil quality under different land cover types within shifting agriculture in South Cameroon. Soil and tillage research. 150, 124-131.

Pandey, C., Singh, A., Sharma, D. (2000). Soil properties under Acacia nilotica trees in a traditional agroforestry system in central India. Agroforestry systems. 49, 53-61.

Parjono, P., Anwar, S., Murtilaksono, K., Indriyati, L. (2019). FRACTIONATION OF IRON (Fe) AND MANGANESE (Mn) IN THE HORIZONS OF A FOREST SOILS, AGROFORESTRY, AND DRYLAND AGRICULTURE. Journal of Environmental Science and Sustainable Development. 2, 9.

Parveen, S., Tripathi, A.K., Pundir, A.K. (2019). Comparative study of physico-chemical properties of soil under different canopies in Jhansi. International Journal of Pharmacy \& Life Sciences. 10. 
Paul, E.A. (2016). The nature and dynamics of soil organic matter: plant inputs, microbial transformations, and organic matter stabilization. Soil Biology and Biochemistry. 98, 109-126.

Prakash, D., Benbi, D.K., Saroa, G.S. (2018). Land-use effects on phosphorus fractions in Indo-Gangetic alluvial soils. Agroforestry systems. 92, 437-448.

Prasad, R., Singh, R., Handa, A., Alam, B., Shukla, A., Singh, P., Tripathi, V., Kumar, D., Kumar, A., Prasad, N. (2019). Dynamics of soil characteristics in eight-years old agrihorti-silviculture model in Bundelkhand region of Central India. Indian Journal of Agroforestry. 21, 27-34.

Prescott, C.E. (2002). The influence of the forest canopy on nutrient cycling. Tree physiology. 22, 1193-1200.

Puttaso, A., Vityakon, P., Saenjan, P., Trelo-Ges, V., Cadisch, G. (2011). Relationship between residue quality, decomposition patterns, and soil organic matter accumulation in a tropical sandy soil after 13 years. Nutrient cycling in agroecosystems. 89, 159-174.

Rocha Junior, P.R.d., Ribeiro, P.H., Mesquita, L.F., Andrade, F.V., Mendonça, E.d.S. (2018). Distribution of $\mathrm{C}$ and inorganic phosphorus fractions in different aggregate sizes under forestry, agroforestry system and pasture. Journal of soil science and plant nutrition. 18, 361-375.

Roy, E.D., Richards, P.D., Martinelli, L.A., Della Coletta, L., Lins, S.R.M., Vazquez, F.F., Willig, E., Spera, S.A., VanWey, L.K., Porder, S. (2016). The phosphorus cost of agricultural intensification in the tropics. Nature plants. 2, 16043.

Sahin, H., Anderson, S., Udawatta, R. (2016). Water infiltration and soil water content in claypan soils influenced by agroforestry and grass buffers compared to row crop management. Agroforestry systems. 90, 839-860.

Salgado, G.M., Gama-Rodrigues, E.F., Vicente, L.C., Gama-Rodrigues, A.C., Aleixo, S., Marques, J.R.B. (2019). Stable carbon in soils under rubber tree (Hevea brasiliensis) agroforestry systems in the south of Bahia, Brazil. SN Applied Sciences. 1, 790.

Saqib, M., Akhtar, J., Abbas, G., Murtaza, G. (2019). Enhancing Food Security and Climate Change Resilience in Degraded Land Areas by Resilient Crops and Agroforestry, Climate Change-Resilient Agriculture and Agroforestry. Springer, pp. 283-297.

Sarabia, L., Solorio, F.J., Ramírez, L., Ayala, A., Aguilar, C., Ku, J., Almeida, C., Cassador, R., Alves, B.J., Boddey, R.M. (2020). Improving the Nitrogen Cycling in Livestock 
Systems Through Silvopastoral Systems, Nutrient Dynamics for Sustainable Crop Production. Springer, pp. 189-213.

Sarminah, S., Karyati, K., Karmini, K., Simbolon, J., Tambunan, E. (2018). Rehabilitation and soil conservation of degraded land using sengon (Falcataria moluccana) and peanut (Arachis hypogaea) agroforestry system. Biodiversitas Journal of Biological Diversity. 19, 222-228.

Schwab, N., Schickhoff, U., Fischer, E. (2015). Transition to agroforestry significantly improves soil quality: A case study in the central mid-hills of Nepal. Agriculture, Ecosystems \& Environment. 205, 57-69.

Sharma, N., Ranjan, R., Pramanik, M., Alam, N. (2016). Dynamics of soil physical and chemical properties under wheat (Triticum aestivum L.)-poplar (Populus deltoides M.) based agroforestry system. Indian Journal of Agroforestry. 18, 41-46.

Shi, S., Zhang, W., Zhang, P., Yu, Y., Ding, F. (2013). A synthesis of change in deep soil organic carbon stores with afforestation of agricultural soils. Forest Ecology and Management. 296, 53-63.

Silva, G., Lima, H., Campanha, M., Gilkes, R., Oliveira, T. (2011). Soil physical quality of Luvisols under agroforestry, natural vegetation and conventional crop management systems in the Brazilian semi-arid region. Geoderma. 167, 61-70.

Singh, H.P. (2016). Effect of nutrient sources on carbon storage and soil fertility underSonaput-tormeric agroforestry system. GB Pant University of Agriculture and Technology, Pantnagar-263145 (Uttarakhand).

Sistla, S.A., Roddy, A.B., Williams, N.E., Kramer, D.B., Stevens, K., Allison, S.D. (2016). Agroforestry practices promote biodiversity and natural resource diversity in Atlantic Nicaragua. PloS one. 11, e0162529.

Solanki, R., Arora, S. (2015). Leaf litter dynamics in Agroforestry system affecting microbial activity in Saline Soils.

Solanki, V.K. (2017). To Study the Nutrient Status in Soil and Plant after the Harvesting of the Tuber Crops under Three-tier Agroforestry System. International Journal of Bioresource and Stress Management. 8, 773-778.

Sousa Neto, O.N.d., Dias, N.d.S., Silva, E.F.d., Ferreira, A.L.L., Fernandes, C.d.S. (2018). Inceptisol Physicochemical Attributes in the Caatinga Biome Agroforestry Systems. Floresta e Ambiente. 25. 
Throop, H., Archer, S., Monger, H., Waltman, S. (2012). When bulk density methods matter: Implications for estimating soil organic carbon pools in rocky soils. Journal of Arid Environments. 77, 66-71.

Tongkaemkaew, U., Sukkul, J., Sumkhan, N., Panklang, P., Brauman, A., Ismail, R. (2018). Litterfall, litter decomposition, soil macrofauna, and nutrient content in rubber monoculture and rubber-based agroforestry plantations. Forest and Society. 2, 138149.

Torralba, M., Fagerholm, N., Burgess, P.J., Moreno, G., Plieninger, T. (2016). Do European agroforestry systems enhance biodiversity and ecosystem services? A meta-analysis. Agriculture, ecosystems \& environment. 230, 150-161.

Tscharntke, T., Clough, Y., Bhagwat, S.A., Buchori, D., Faust, H., Hertel, D., Hölscher, D., Juhrbandt, J., Kessler, M., Perfecto, I. (2011). Multifunctional shade-tree management in tropical agroforestry landscapes-a review. Journal of Applied Ecology. 48, 619629.

Udawatta, R.P., Anderson, S.H. (2008). CT-measured pore characteristics of surface and subsurface soils influenced by agroforestry and grass buffers. Geoderma. 145, 381389.

Udawatta, R.P., Gantzer, C.J., Jose, S. (2017). Agroforestry practices and soil ecosystem services, Soil Health and Intensification of Agroecosytems. Elsevier, pp. 305-333.

Udawatta, R.P., Anderson, S.H., Gantzer, C.J., Garrett, H.E. (2006). Agroforestry and grass buffer influence on macropore characteristics. Soil Science Society of America Journal. 70, 1763-1773.

Udawatta, R.P., Kremer, R.J., Garrett, H.E., Anderson, S.H. (2009). Soil enzyme activities and physical properties in a watershed managed under agroforestry and row-crop systems. Agriculture, ecosystems \& environment. 131, 98-104.

Uthappa, A., Bana, O., Kumar, M., Kanwal, M. (2015). Soil physico-bio-chemical properties as influenced by varying tree densities in poplar (Populus deltoides Bartr. ex Marsh.) based agroforestry system. Indian Journal of Agroforestry. 17, 81-90.

Vallejo, A.M. (2014). From soil nutrient balances to regional policy analysis: a case study of integrated assessment in Machakos, Kenya. Wageningen University.

Waldron, A., Garrity, D., Malhi, Y., Girardin, C., Miller, D., Seddon, N. (2017). Agroforestry can enhance food security while meeting other sustainable development goals. Tropical Conservation Science. 10, 1940082917720667. 
Wang, J., Ren, C., Cheng, H., Zou, Y., Bughio, M.A., Li, Q. (2017). Conversion of rainforest into agroforestry and monoculture plantation in China: consequences for soil phosphorus forms and microbial community. Science of the Total Environment. 595, 769-778.

Weerasekara, C., Udawatta, R.P., Jose, S., Kremer, R.J., Weerasekara, C. (2016). Soil quality differences in a row-crop watershed with agroforestry and grass buffers. Agroforestry Systems. 90, 829-838.

Yadav, R., Yadav, B., Chhipa, B., Dhyani, S., Ram, M. (2011). Soil biological properties under different tree based traditional agroforestry systems in a semi-arid region of Rajasthan, India. Agroforestry systems. 81, 195-202.

Yu, W. (2018). The Effect of the Application of Different Agroforestry Techniques on Soil $\mathrm{pH}$.

Ziter, C., MacDougall, A.S. (2013). Nutrients and defoliation increase soil carbon inputs in grassland. Ecology. 94, 106-116. 